\title{
Native-plant hosts of Meloidogyne spp. from Western Paraná, Brazil
}

\author{
Vanessa A. Antes ${ }^{1}$, Anna P. Comerlato ${ }^{1}$, Adílson Ricken Schuelter ${ }^{2}$, Regina M.D.G. \\ Carneiro $^{3}$ and Cleber Furlanetto ${ }^{4 *}$ \\ ${ }^{I}$ Universidade Estadual do Oeste do Paraná; Laboratório de Nematologia; Marechal Cândido Rondon - PR - \\ Brasil. ${ }^{2}$ Cooperativa Central de Pesquisa Agrícola; Cascavel - PR - Brasil. ${ }^{3}$ Embrapa Recursos Genéticos e \\ Biotecnologia; Brasília - DF - Brasil. ${ }^{4}$ Universidade de Brasília; Departamento de Fitopatologia; 70.910-900; \\ Brasília - DF - Brasil
}

\begin{abstract}
The present study was focused on the parasitism of Meloidogyne species on the roots of native nursery plants from the Atlantic forest. Native plants were selected from a commercial nursery in Western Paraná, searching for the natural infection of Meloidogyne. Also, the seeds of native plants were cultivated in sterile soil and inoculated with $M$. incognita. In both the experiments, the number of galls and number of eggs and J2 per root, allied to the reproduction factor of $M$. incognita on each inoculated plant were assessed. Natural infection by M. javanica was found on Cordia ecalyculata, Citharexyllum myrianthum and Aspidosperma subincanum and by M. incognita on Croton urucurana, Lonchocarpus muehlbergianus, Tabebuia impetiginosa and T. serratifolia. Meloidogyne incognita induced galls formation on Genipa americana, Schinus terebinthifolius and Rollinia mucosa after inoculation, which suggested that those plants could host this nematode in natural biomes. Nursery soil should be disinfested before seeding the native forest plants for reforestation purposes
\end{abstract}

Key words: Atlantic forest, native-plants, Root-knot nematodes

\section{INTRODUCTION}

Meloidogyne spp. are one of the most important plant-parasitic nematodes in the world, showing a wide distribution and a large host range. In Western Paraná, Meloidogyne species cause economical damages to different crops such as soybean (Roese et al. 2001; Franzener et al. 2005), cotton (Pires et al. 2008) and coffee (Portz et al. 2006), among others.

Western Paraná, located at Paraná state, south of Brazil, presents a semi-deciduous subtropical forest called "The Upper Paraná Atlantic Forest" in which most of native plants belong to the Atlantic forest biome (Di Bitetti et al. 2003).
Despite being fragmented, Atlantic forest is still considered one of the hot spots for fauna and flora biodiversity for conservation purposes (Myers et al. 2000).

Regarding the Atlantic Forest only $12 \%$ remains intact. Therefore, the preservation of areas covered by the Atlantic forest as well as the implementation of reforestation programs in Brazil will aid to protect the forest biodiversity and to promote its sustainable development. A reforestation project involving the Climate, Community and Biodiversity Alliance (CCBA) and partnerships has started in 2008. This project aims to revive 1,000 hectares of Atlantic Forest located between the National Parks of Monte

*Author for correspondence: cfurla@ hotmail.com 
Pascoal and Pau Brasil. The forest recovery will also contribute to remove 360,000 tons of carbon over 30 years. Certainly, the success of this project will contribute to prioritize the actions towards the preservation and reforestation of the Atlantic Forest in Brazil. (Donsky and Boyer 2010).

The biodiversity of the fauna and flora of the Atlantic Forest has been well characterized but not that related to the nematodes, particularly rootknot nematodes. Surveys on Meloidogyne spp. have been carried out in Atlantic forest (Lima et al. 2005) reporting the presence of $M$. incognita, $M$. javanica, $M$. arenaria, $M$. enterolobii $(=M$. mayaguensis), and M. exigua. For other Brazilian biomes such as "cerrado" or brazilian savannah (Souza et al. 1994; Huang et al. 1996; Cares and Huang 1991; Cares and Huang 2008), M. javanica and $M$. arenaria race 2 were reported and for the Amazon forest (Cares and Huang 2008; Silva et al. 2008) $M$. javanica has also been reported. Currently, there is no information for the native forests from Western Paraná regarding to the parasitism of Meloidogyne spp.

The challenges found in the native areas when searching for root-plant parasites are mainly related to the mix of the roots at the rhizosphere of plants, which makes difficult to identify their putative hosts. As the Atlantic forest is composed of dense vegetation, different strategies were adopted in the present work to assess the parasitism of Meloidogyne on native plants: 1. A survey was carried out in a commercial nursery aiming to analyze roots of plants grown in nonsterile soil, as a way to search for the natural infection of Meloidogyne spp.; 2. Artificial inoculation was provided to the plants cultivated in sterile soil to evaluate Meloidogyne parasitism on the native plants.

\section{MATERIALS AND METHODS}

\section{Search for Meloidogyne spp. on native plant seedlings from a commercial nursery}

In order to detect Meloidogyne spp. infecting the native plants, a survey was carried out on the plant seedlings from a commercial nursery belonging to the Western Paraná State University. The assay was arranged in a completely randomized design containing 36 different treatments (plant species) and five replications. All the selected plants had the same age (one year old) and received a standard treatment in the nursery such as daily watering, ten granules of fertilizer $\mathrm{N}(4)-\mathrm{P}(14)$ -
$\mathrm{K}(8)$ applied to each plant every three months and fungicide application to control the shoot diseases when necessary. The seedlings were kept into a 3 $\mathrm{Kg}$ black plastic bag of $30 \mathrm{~cm}$ depth and $10 \mathrm{~cm}$ wide, filled with non-sterile soil.

The plant root systems were washed and analyzed for the presence of galls caused by Meloidogyne spp. From the galls, single females (ten from each root plant) were extracted and Meloidogyne species were identified by esterase phenotype, according to Esbenshade and Triantaphyllou (1985). Briefly, the extracted proteins from single females were run in a MGV-202 electrophoresis system (Biosystems). Esterase phenotypes were visualized on polyacrilamide gels $8 \%$ and stained with $0.1 \%$ fast blue RR and $\alpha$-naftil acetate (Sigma) stains. The relative mobility (Rm) of esterase in the gels was calculated by the equation: migration distance of each band/distance of the front dye (bromophenol blue). The $\mathrm{Rm}$ provided information about the molecular weight of molecules according to their migration in gels. For Meloidogyne identification, M. javanica is usually used as a standard for comparison with other species. In this study, populations of $M$. javanica were found on the root system of some hosts and were used for comparison in the gels (Fig. 1).

In addition, the number of eggs and $\mathrm{J} 2$ stages were evaluated per root system. In this sense, the roots were washed in tap water, cut into small pieces and triturated in a blender for 30 seconds under low rotation, following Coolen and D'Herbe (1972). The reproduction factor (RF) was not considered at this first stage because the initial population was unknown.

\section{Artificial inoculation of $M$.incognita}

Artificial inoculation of $M$. incognita (Est I1) was accomplished on the 29 native plant species that did not demonstrate natural infection by Meloidogyne spp. (Table 1). This assay was conducted in a greenhouse with temperature and air humidity ranging from 11.1 to $31.7{ }^{\circ} \mathrm{C}$ and from 36.4 and $97.3 \%$, respectively. A completely randomized design with 29 treatments (plant species) and four replications was arranged for this experiment. One population of $M$. incognita, extracted from the roots of Tabebuia impetiginosa, was multiplied on tomato plants in a greenhouse and used as inoculum source. Each native-plant species was seeded in the plastic pots filled with 3 $\mathrm{Kg}$ of sterile soil. The soil was sterilized by autoclaving at $120{ }^{\circ} \mathrm{C}$ for 1 hour. A single plant, 
three months of age, was used per plastic pot. The plants were inoculated with 5,000 eggs and second-stage juveniles (J2) of $M$. incognita and were evaluated after sixty days. The evaluation procedure involved the washing of each plant root to record the number of galls. The process of eggs and $\mathrm{J} 2$ extraction was performed as previously mentioned, following Coolen and D'Herbe's methodology (1972). The reproduction factor (RF) was calculated according to the formula $\mathrm{RF}=$ $\mathrm{Pi} / \mathrm{Pf}$, where the $\mathrm{Pf}$ represented the final and the $\mathrm{Pi}$ the initial population. In this study, the initial population was 5,000 eggs and $\mathrm{J} 2$, both considered as a single value to calculate the RF. The RF is used to measure the reproductive ability of nematodes on a given host. Therefore, hosts are considered resistant when $\mathrm{RF} \geq 1.0$ and susceptible when $\mathrm{RF} \leq 1.0$.

\section{RESULTS AND DISCUSSION}

From 36 native-plant species surveyed, seven were naturally infected by $M$. incognita (Est I1, Rm: 1.0) or M. javanica (Est J3, Rm: 1.0, 1.25 and
1.33) (Fig. 1). Meloidogyne incognita was found on the roots of Lonchocarpus muehlbergianus, Tabebuia impetiginosa, Croton urucurana and Tabebuia serratifolia, whereas $M$. javanica occurred on Cordia ecalyculata, Cytharexyllum myrianthum and Aspidosperma subincanum (Table 1 ). The average of galls on the roots of naturallyinfected plants ranged from 8 to 129 , while the number of eggs andlor $\mathrm{J} 2$ per root system ranged from 87 to 5,733 (Table 2). These plants could be considered new hosts for $M$. incognita and $M$. javanica since no previous records were found in the literature.

Of the 29 plant species artificially-inoculated with M. incognita, only Genipa Americana, Schinus terebinthifolius, and Rollinia mucosa presented susceptibility to this nematode species. Variations were observed in the reproductive factors as a result of artificial inoculation of $M$. incognita on Genipa Americana $(\mathrm{RF}$ average $=0.45)$, Schinus terebinthifolius $(\mathrm{RF}$ average $=1.73)$ and Rollinia mucosa (RF average $=1.2$ ). From these plants, Schinus terebinthifolius and Rollinia mucosa showed $\mathrm{RF} \geq 1.0$ and could be considered as good hosts for this nematode.

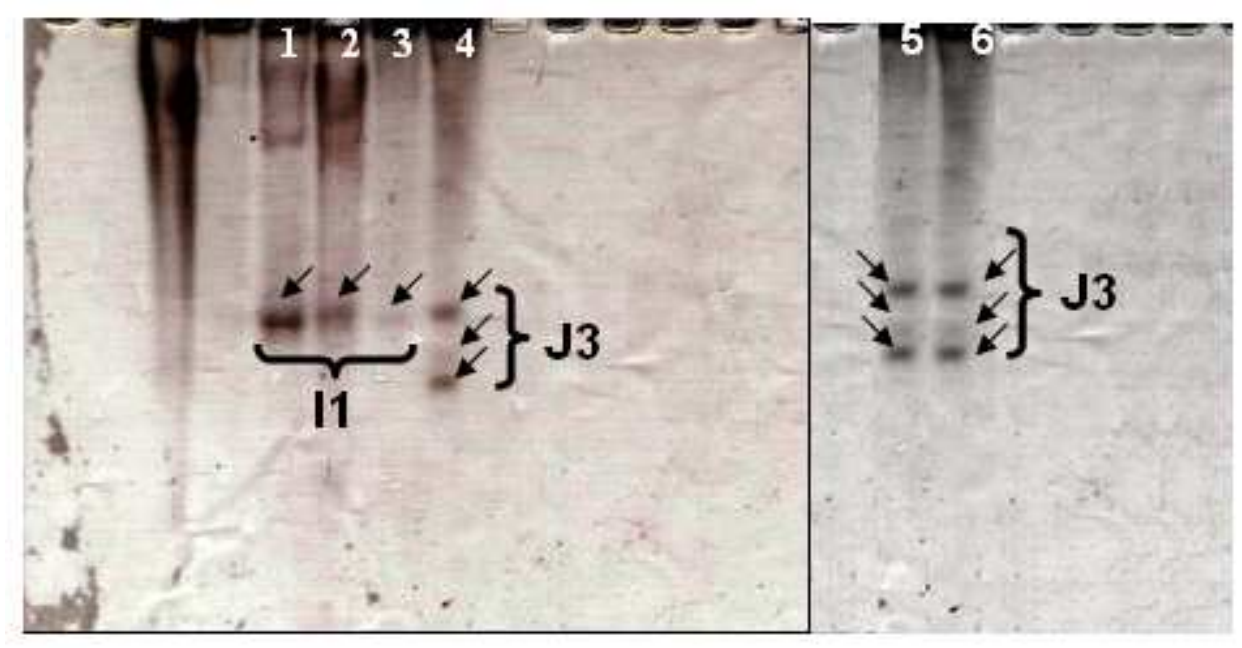

Figure 1 - Esterase phenotypes of M. incognita (I1) and M. javanica (J3) displayed in two polyacrylamide gels: Gel 1: Lonchocarpus muehlbergianus (1), Croton urucurana (2), Tabebuia impetiginosa (3), Cordia ecalyculata (4); Gel 2: Cytharexyllum myrianthum (5) and Aspidosperma subincanum (6). 
Table 1 - Seedlings of native plants collected from the commercial nursery of the Western Paraná State University and assessed for infection of Meloidogyne spp.

\begin{tabular}{|c|c|c|c|}
\hline Plant species & Common Name/Family & Natural host* & $\begin{array}{c}\text { Inoculated } \\
\text { hosts** }\end{array}$ \\
\hline Adenanthera pavonina L. & Red sandalwood tree/ Fabaceae Mimosoideae & & \\
\hline Albizia polycephala (Benth.) & Farinha-seca/Fabaceae Mimosoideae & & \\
\hline Killip ex Record. & & & \\
\hline $\begin{array}{l}\text { Anadenanthera macrocarpa } \\
\text { (Benth.) Brenan }\end{array}$ & Angico Vermelho/ Fabaceae Mimosoideae & & \\
\hline Aspidosperma subincanum Mart.\# & Guatambu/Apocynaceae & M. javanica & \\
\hline Bauhinia longifolia (Bong.) Steud. & Pata de vaca/ Fabaceae Caesalpinoideae & & \\
\hline Cabralea canjerana (Vell.) Mart. & Canjerana/Meliaceae & & \\
\hline $\begin{array}{l}\text { Caesalpinia ferrea Mart. Ex. Tul. } \\
\text { var. leiostachya Benth. }\end{array}$ & Iron Wood/Fabaceae Caesalpinoideae & & \\
\hline Cedrela fissilis Vell. & Cedro/Meliaceae & & \\
\hline Chorisia speciosa A. St.-Hil. & Paineira/Bombacaceae & & \\
\hline Cordia ecalyculata Vell.\# & Café de bugre/Boraginaceae & M. javanica & \\
\hline $\begin{array}{l}\text { Cordia trichotoma (Vell.) Arrab. } \\
\text { ex Steud. }\end{array}$ & Frei Jorge 1/Boraginaceae & & \\
\hline Croton urucurana Boill.\# & Dragon's blood/Euphorbiaceae & M. incognita & \\
\hline Cytharexyllum myrianthum Cham\# & Taruma Branco/Verbenaceae & M. javanica & \\
\hline $\begin{array}{l}\text { Enterolobium contortisiliquum } \\
\text { (Vell.) Morong }\end{array}$ & earpod tree/Fabaceae Mimosoideae & & \\
\hline Eugenia involucrata DC. & Cherry of the Rio Gande/ Myrtaceae & & \\
\hline Eugenia uniflora $\mathrm{L}$. & Brazilian cherry/Myrtaceae & & \\
\hline Genipa americana L.\# & Genipap/Rubiacea & & M. incognita \\
\hline Inga laurina & Ice cream bean/Fabaceae Mimosoideae & & \\
\hline Jacaranda micrantha Cham & Jacaranda/Bignoniaceae & & \\
\hline $\begin{array}{l}\text { Lonchocarpus muehlbergianus } \\
\text { Hassl.\# }\end{array}$ & Rabo de Bugio/Fabaceae Faboideae & $M$ incognita & \\
\hline Luehea paniculata Mart. & Açoita-cavalo/Tiliaceae & & \\
\hline $\begin{array}{l}\text { Maclura tinctoria (L.) D. Don ex } \\
\text { Steud. }\end{array}$ & Dyer's mulberry; Fustic mulberry/ Moraceae & & \\
\hline Myrcianthes pungeus (Berg) Legr. & Guabiju/Myrtaceae & & \\
\hline Myrocarpus frondosus & Cabreuva/Fabaceae Faboideae & & \\
\hline Allemao & & & \\
\hline $\begin{array}{l}\text { Parapiptadenia rigida (Benth.) } \\
\text { Brenan }\end{array}$ & Angico gurucaia/Fabaceae Mimosoideae & & \\
\hline Patagonula americana $\mathrm{L}$. & Guajuvira/Boraginaeae & & \\
\hline $\begin{array}{l}\text { Peltophorum dubium } \\
\text { (Spreng.)Taub. }\end{array}$ & Canafístula/Fabaceae Caesalpinoideae & & \\
\hline Prunus sellowii Kochne & Pessegueiro Bravo/Rosaceae & & \\
\hline Psidium cattleianum Sabine & Strawberry guava/Myrtaceae & & \\
\hline Pterogyne nitens Tul. & Amendoim bravo/Fabaceae Caesalpinoideae & & \\
\hline Rollinia mucosa (Jacq.) Baill.\# & Biriba/Annonaceae & & M. incognita \\
\hline Ruprechtia laxiflora Meisn. & Marmeleiro/Polygonaceae & & \\
\hline Schinus terebinthifolius Raddi. & Brazilian Pepper-tree/ Anacardiaceae & & M. incognita \\
\hline Tabebuia heptaphylla (Vell.) Tol. & Ipê Rosa/Bignoniaceae & & \\
\hline $\begin{array}{l}\text { Tabebuia impetiginosa (Mart. Ex } \\
\text { DC.) Standl }\end{array}$ & Taheebo; Pau d'Arco tree/ Bignoniaceae & M. incognita & \\
\hline Tabebuia serratifolia (Vahl.) Nich. & Yellow poui/Bignoniaceae & M. incognita & \\
\hline
\end{tabular}


Table 2 - Native plants naturally infected by Meloidogyne incognita and M. javanica according to the esterase phenotype (Est). Population assessments based on number of galls, number of eggs and $\mathbf{J} 2$ per root system.

\begin{tabular}{lccl}
\hline Common name & Number of galls & Eggs and J2** & Nematode\# \\
\hline Lonchocarpus muehlbergianus* & 61 & 680 & M. incognita Est (I1) \\
Tabebuia impetiginosa & 8 & 86 & M. incognita Est (I1) \\
Cordia ecalyculata & 10 & 226 & M. javanica Est (J3) \\
Cytharexyllum myrianthum & 129 & 5.733 & M. javanica Est (J3) \\
Aspidosperma subincanum & 23 & 466 & M. javanica Est (J3) \\
Croton urucurana & 35 & 333 & M. incognita Est (I1) \\
Tabebuia serratifolia & 54 & 760 & M. incognita Est (I1) \\
\hline
\end{tabular}

*Average of 4 replicates per treatment (host plant). **Missing 10 females per root used for Meloidogyne identification by esterase phenotype; \#RF was not calculated due to the lack of information about the initial population.

Meloidogyne incognita and M. javanica are the most widespread nematodes in the cultivated lands of Western Paraná, Brazil, infecting the main crops (Roese et al. 2001; Franzener et al. 2005; Portz et al. 2006; Pires et al. 2008). In this survey, these nematodes were also found on the roots of native-plant seedlings which have been commonly used for reforestation.

Tabebuia serratifolia and T. impetiginosa had been previously reported as the hosts of $M$. javanica and M. arenaria (Ferreira 1989; Mendes and Cardoso 1978). However, in this work, only $M$. incognita was detected infecting these plants. Close-related plants, such as those belonging to a same genus or family, presented different reactions when inoculated with $M$. incognita. In the genus Tabebuia (Bignoniaceae), M. incognita infected $T$. impetiginosa and $T$. serratifolia but not $T$. heptaphylla and in the Fabaceae/Faboidea, $M$. incognita infected Lonchocarpus muehlbergianus but not Myrocarpus frondosus. Moreover, considering the susceptible treatments (native plants) $M$. incognita was not virulent to all the replicates. Therefore, the different reactions found on replicates of a same plant species or on plants belonging to a same family or genus might indicate genetic diversity among the native plants within preserved areas.

Meloidogyne incognita was also detected in the soil samples collected at the rhizosphere of Miconia cinnamonifolia Naud. and Sclerolobium sp. from the Atlantic forest, whilst M. javanica was detected at the rhizosphere of several other native plants (Lima et al. 2005). The same authors also reported $M$. javanica at the rhizosphere of Eugenia leitonni (myrtaceae) in the Atlantic forest. However, in this study, native species belonging to the Myrtaceae family did not present infection for $M$. javanica or for $M$. incognita, even after $M$. incognita inoculation.

The parasitism of $M$. incognita and $M$. javanica was also obtained by seedlings inoculation of Pinus and Eucalyptus as reported by Ferraz and Lordello (1982) and Ferraz (1986). Other hosts for M. incognita included Hevea brasiliensis (Muell.) Arg. (Freire 1976) and Psidium guajava L. (Piccinin et al. 2005): the latter was also parasited by $M$. mayaguensis Rammah and Hirschmann, 1988 (Carneiro et al. 2001, Torres et al. 2004; Torres et al. 2005, and Silva et al. 2006).

Another host for Meloidogyne was Luehea paniculata from the Atlantic forest biome, which was found in association with M. exigua in the soil samples collected at its rhizosphere. In this work, this plant was not infected by both $M$. incognita and $M$. javanica. This suggested that $L$. paniculata might host $M$. exigua but not $M$. incognita and $M$. javanica.

In the biome Cerrado, Huang et al. (1991) detected natural infection of $M$. javanica and $M$. arenaria on the roots of Dimophandra mollis Benth. (Fabaceae) and Cybianthus gardneri A. DC. (Myrsinaceae), respectively. In native cerrado vegetation, Huang et al. (1996) reported a nonidentified species of Meloidogyne from the soil samples collected at the rhizosphere of Pterodon pubescens Benth, 1860.

So far, the methodologies employed for Meloidogyne surveys on the native forests were mostly focused on collecting the soil samples from random sites and using bait plants such as tomato (Solanum lycopersicum L.) as an alternative to reproducing and identifying Meloidogyne species present in the soil (Huang et al. 1996; Souza et al. 1994; Lima et al. 2005). These methodologies previously used were successfully applied to the study of Meloidogyne diversity in different types of vegetation. However, they did not present 
sufficient accuracy to associate Meloidogyne species with their putative hosts. Silva et al. (2008) were not able to identify a putative host for $M$. exigua by collecting the roots from the sites covered by the native Amazon forest. These results could be mainly associated with the high density of plant roots present at the collecting sites, which made the process of plant-nematode association very difficult. Therefore, the approach employed in this work could be useful when searching for plant-hosts of Meloidogyne in native biomes.

Nevertheless, the detection of Meloidogyne spp., as shown in this study, on the seedlings of native plants used for reforestation was a sign that more stringent protocols would be needed for soil sterilization (e.g. fumigation, solarization, or some additional treatment) prior to the propagation of these plants. Moreover, the use of sterile synthetic substrate for seedlings production, would also contribute to the sanity of the plants. Such approaches would strongly contribute to reducing the introduction and dissemination of Meloidogyne spp. and other plant pathogens in reforestation areas as well as it would reduce the environmental imbalances within the preserved areas.

\section{ACKNOWLEDGEMENTS}

This project received financial support of the National Council for Scientific and Technological Development (CNPq, Brazil - project 479922/063). Cleber Furlanetto is productivity Research Fellow from CNPq.

\section{REFERENCES}

Cares JE, Huang SP. Nematode fauna in natural and cultivated cerrados of central Brazil. Fitopatol Bras. 1991;16: 199-209.

Cares JE, Huang SP. Comunidades de nematóides de solo sob diferentes sistemas na Amazônia e Cerrados brasileiros. In: Moreira F, Siqueira JO, Brussaard L, editors. Biodiversidade do solo em ecossistemas brasileiros, Lavras: UFLA; 2008. p. 409-444.

Carneiro RMDG, Moreira WA, Almeida MRA, Gomes ACMM. Primeiro registro de Meloidogyne mayaguensis em goiabeira no Brasil. Nematol Bras. 2001;25:223-228.
Coolen WA, D'herbe CJ. A method for the quantitative extraction of nematodes from plant tissue. Ghent: Belgium; 1972.

Di Bitetti MS, Placci G, Dietz LA. A Biodiversity vision for the Upper Paraná Atlantic Forest Ecoregion: Designing a Biodiversity Conservation Landscape and Setting Priorities for Conservation Action. World wildlife Fund: Washington; 2003. $137 p$.

Donsky A, Boyer R. Reforestation in Brazil's Atlantic Forest could help biodiversity recover [Internet]. 2010 Feb 19 [cited 2010 Oct 17]. Available from http://www.treehugger.com/.

Esbenshade PR, Triantaphyllou AC. Eletrophoretic methods for the study of root-knot nematode enzymes. In: Barker KR, Carter CC, Sasser JN, editors. An advanced treatise on Meloidogyne. North Carolina State University Graphics: Raleigh NC, USA. 1985; p. 115-123.

Ferraz LCCB, Lordello LG. Suscetibilidade e danos causados a espécies de Eucalyptus e Pinus por nematoides das galhas no Estado de São Paulo. Rev Agric. 1982;57:67-73.

Ferraz LCCB. Observações histopatológicas em raízes de Eucaliptus citriodora Hk. e Pinus caribea var. caribea Mor. parasitadas por nematoides das galhas. Fitopatol Bras. 1986;7: 91-96.

Ferreira FA. Doenças florestais no Brasil causadas por nematoides, bactérias, vírus, viróides, micoplasmas e espiroplasmas. In: Ferreira A, editor. Patologia Florestal. Viçosa:UFV; 1989. p. 515-520.

Franzener G, Unfried JR, Stangarlin JR, Furlanetto C. Nematoides formadores de galha e de cisto patogenicos a cultura da soja em municipios do oeste do Parana. Nematol Bras. 2005;29:261-265.

Freire FCD. Nematoides da região amazônica I Nematoides parasitas e de vida livre associados à seringueira (Hevea brasiliensis Muell. Arg.) e ao guaraná (Paullinia cupuana var. sorbillis). Acta Amaz. 1976;6:401-404.

Huang SP, Pereira AC, Dristig MCG, Souza RM. Ocorrência de Meloidogyne javanica e Meloidogyne arenaria em árvores silvestres no cerrado virgem do Brasil Central. Fitopatol Bras. 1991;16 SUPPL:p.37.

Huang SP, Freire HCA, Cares JE. Grupos composicionais e tróficos dos nematóides associados à sucupira branca (Pterodon pubescens) em cerrado nativo. Fitopatol Bras. 1996;21:156-160.

Lima IM, Souza RM, Silva CP, Carneiro RMDG. Meloidogyne spp. from preserved areas of Atlantic Forest in the state of Rio de Janeiro, Brazil. Nematol Bras. 2005;29:31-38. 
Mendes BV, Cardoso CON. Algumas observações histopatológicas de raízes de ipê roxo parasitadas por Meloidogyne arenaria. Summa Phytopathol. 1978;4:49-54.

Myers N, Mittermeier RA, Mittermeir CG, Fonseca $\mathrm{GAB}$, Kent J. Biodiversity hotspots for conservation priorities. Nature. 2000;403:853-858.

Piccinin E, Pascholati SF, Di Piero RM. Doenças da Goiabeira (Psidium guajava). In: Kimati H, Amorim L, Rezende JAM, Bergamin Filho A, Camargo LEA, editors. Piracicaba: Agronômica Ceres; 2005, p. 401405.

Pires E, Santana H, Nasu EGC, Furlanetto C. Ocorrência de Meloidogyne incognita raça 3 em Lavouras de Algodão na Região Noroeste do Paraná. Nematol Bras. 2008;32:81-83.

Portz RL, Stangarlin JR, Franzener G, Balbi-Peña MI, Furlanetto C. Meloidogyne spp. associated to coffee plantations in counties of Western Paraná, Brazil. Nematol Bras. 2006;30:23-27.

Roese AD, Romani RD, Furlanetto C, Stangarlin JR, Portz RL. Levantamento de doencas na cultura da soja, Glycine $\max (\mathrm{L}$.$) Merril, em municipios da$ regiao oeste do estado do Parana. Acta Scient. 2001;23:1293-1297.
Silva GS, Sobrinho CA, Pereira AL, Santos JM. Ocorrência de Meloidogyne mayaguensis em goiabeira no Estado do Piauí. Nematol Bras. 2006;30:307-309.

Silva RA, Oliveira CMG, Inomoto MM. Fauna of plantparasitic nematodes in natural and cultivated areas of the Amazon forest, Mato Grosso State, Brazil. Trop P Pathol. 2008;33:204-211.

Souza RM, Dolinski CM, Huang SP. Survey of Meloidogyne spp. in native cerrado of Distrito Federal, Brazil. Fitopatol Bras. 1994;19:463-465.

Torres GRC, Sales Júnior R, Rehn VNC, Pedrosa EMR, Moura RM. Meloidogyne mayaguensis em Psidium guajava no Rio Grande do Norte. Fitopatol Bras. 2004;29:570.

Torres GRC, Sales Júnior R, Rehn VNC, Pedrosa EMR, Moura RM. Ocorrência de Meloidogyne mayaguensis em goiabeira no Estado do Ceará. Nematol Bras. 2005;29:105-107. 


$$
\begin{gathered}
\text { PAGINA } \\
\text { EM } \\
\text { BRANCO }
\end{gathered}
$$

